\title{
Sublethal Oxidative Stress Induces the Premature Senescence of Human Mesenchymal Stem Cells Derived from Endometrium
}

\author{
Elena Burova, Aleksandra Borodkina, Alla Shatrova, and Nikolay Nikolsky \\ Department of Intracellular Signaling and Transport, Institute of Cytology of Russian Academy of Sciences, \\ St. Petersburg 194064, Russia \\ Correspondence should be addressed to Elena Burova; burova_elena@yahoo.com
}

Received 10 June 2013; Revised 19 July 2013; Accepted 19 July 2013

Academic Editor: Mohammad Abdollahi

Copyright (C) 2013 Elena Burova et al. This is an open access article distributed under the Creative Commons Attribution License, which permits unrestricted use, distribution, and reproduction in any medium, provided the original work is properly cited.

\begin{abstract}
The specific responses of mesenchymal stem cells to oxidative stress may play a crucial role in regulation of tissue homeostasis as well as regeneration of organs after oxidative injury. The responses of human endometrium-derived mesenchymal stem cells (hMESCs) to oxidative stress remain still unknown. Herein, we examined the impact of $\mathrm{H}_{2} \mathrm{O}_{2}$ on cell viability, induction of premature senescence, and apoptosis. hMESCs were highly resistant to $\mathrm{H}_{2} \mathrm{O}_{2}$ compared with human diploid fibroblasts. To test a hypothesis whether hMESCs may undergo oxidative stress-induced premature senescence, cells were briefly exposed to the sublethal $\mathrm{H}_{2} \mathrm{O}_{2}$ doses. $\mathrm{H}_{2} \mathrm{O}_{2}$-treated cells were permanently arrested, lost Ki67 proliferation marker, and exhibited a senescent phenotype including cell hypertrophy and increased SA- $\beta$-Gal activity. Additionally, in stressed cells the expression levels of p21Cip1, SOD1, SOD2, and GPX1 were elevated. hMESCs survived under stress were not able to resume proliferation, indicating the irreversible loss of proliferative potential. While the low $\mathrm{H}_{2} \mathrm{O}_{2}$ doses promoted senescence in hMESCs, the higher $\mathrm{H}_{2} \mathrm{O}_{2}$ doses induced also apoptosis in a part of the cell population. Of note, senescent hMESCs exhibited high resistance to apoptosis. Thus, we have demonstrated for the first time that hMESCs may enter a state of premature senescence in response to sublethal oxidative stress.
\end{abstract}

\section{Introduction}

Stress responses of human embryonic and adult stem cells to $\gamma$-radiation, oxidative stress, heat shock, and so forth are widely researched to establish cell-based strategies of tissue repair, tissue engineering, and transplantation [1]. Human mesenchymal stem cells are adult multipotent stem cells with the capacity of self-renewal and undergoing adipogenic, osteogenic, chondrogenic, myogenic differentiation $[2,3]$. They contribute to the homeostatic maintenance of many organs and tissues $[4,5]$. Unlike some other adult stem cells (e.g., hematopoietic stem cells) human mesenchymal stem cells are not immortal. These cells exhibit ex vivo growth characteristics typical of the Hayflick model of cellular senescence with a limited life span [6]. Recently, it has been reported that the mesenchymal stem cells subjected to oxidative stress [79] or ionizing radiation [10-12] may undergo stress-induced premature senescence in vitro. Many types of normal and tumor cells also enter a state of premature senescence after exposure to radiation [13-15], $\mathrm{H}_{2} \mathrm{O}_{2}$ [16-19], or treatment with histone deacetylase inhibitors [20, 21]. Prematurely senescent cells exhibit some of the characteristics inherent in replicatively senescent cells, including a large flat morphology, increased senescence-associated $\beta$-galactosidase (SA- $\beta$ Gal) activity, and permanent cell cycle arrest $[14,17]$. Besides, cellular overactivation and hyperfunction, feedback signal resistance, and loss of regenerative potential are considered hallmarks of senescence [22]. Progress in understanding the causes and mechanisms of cellular senescence and significance of senescence for ageing and suppressing cancer has been reviewed [23-25].

In the current study, oxidative stress responses of human mesenchymal stem cells derived from endometrium (hMESCs) were investigated. Our knowledge of specific responses of these cells to stress is very limited, though they prove to be useful in the treatment of pathologies in which tissue damage is linked to oxidative stress. Unlike most of the human mesenchymal stem cells, the isolation of which as a rule is complicated by invasive procedures, the mesenchymal stem cells produced from desquamated endometrium in 
menstrual blood by a simple noninvasive way provide a good opportunity to explore the stress responses of hMESCs. Regarding hMESCs, phenomenon of premature senescence induced by oxidative stress remains still unknown. This study aimed to test a hypothesis whether hMESCs after exposure with sublethal doses of $\mathrm{H}_{2} \mathrm{O}_{2}$ may undergo the stress-induced premature senescence. In parallel, the impact of $\mathrm{H}_{2} \mathrm{O}_{2}$ on cell viability and development of apoptosis has been evaluated.

\section{Materials and Methods}

2.1. Cell Culture and Cell Treatment. Human mesenchymal stem cells isolated from desquamated endometrium in menstrual blood (hMESCs, line 2304), as described previously [26], as well as human embryonic lung-derived diploid fibroblasts (HDF, line FRL-9505) were cultured in complete medium (DMEM/F12 (Gibco BRL, Gaithersburg, MD, USA) supplemented with $10 \%$ FBS (HyClone, Waltham, MA, USA), $1 \%$ gentamycin, and 1\% glutamax (Gibco BRL, Gaithersburg, $\mathrm{MD}, \mathrm{USA})$ ) at $37^{\circ} \mathrm{C}$ in humidified incubator, containing $5 \%$ $\mathrm{CO}_{2}$. hMESCs have a positive expression of CD73, CD90, CD105, CD13, CD29, and CD44 markers and absence of expression of the hematopoietic cell surface antigens CD19, CD34, CD45, CD117, CD130, and HLA-DR (class II). Multipotency of isolated hMESCs is confirmed by their ability to differentiate into other mesodermal cell types, such as osteocytes and adipocytes. Besides, the isolated hMESCs partially (over 50\%) express the pluripotency marker SSEA-4 but do not express Oct-4. Immunofluorescent analysis of the derived cells revealed the expression of the neural precursor markers nestin and beta-III-tubulin. This suggests a neural predisposition of the established hMESCs. These cells are characterized by high rate of cell proliferation (doubling time 22-23 h) and high cloning efficiency (about 60\%). Cells at early passages (between 6 and 9 passages for hMESCs and between 16 and 21 passages for HDF) were used in all experiments to avoid complications of replicative senescence. Cells were harvested by trypsinization and plated at a density of $15 \times 10^{3}$ cells per $\mathrm{cm}^{2}$. For microscopy experiments, cells were grown on glass coverslips. $\mathrm{H}_{2} \mathrm{O}_{2}$ treatments were performed on subconfluent cells to avoid variability of $\mathrm{H}_{2} \mathrm{O}_{2}$ toxicity. $\mathrm{H}_{2} \mathrm{O}_{2}$ stock solution in serum-free medium was prepared from $30 \% \mathrm{H}_{2} \mathrm{O}_{2}$ (Sigma, St. Louis, MO, USA) just before adding. Cells were treated with $\mathrm{H}_{2} \mathrm{O}_{2}$ in the range of concentrations from $200 \mu \mathrm{M}$ to $2,000 \mu \mathrm{M}$ for $1 \mathrm{~h}$ for MTT assay. Based on $\mathrm{LD}_{50}$ values $200 \mu \mathrm{M} \mathrm{H} \mathrm{H}_{2} \mathrm{O}_{2}$ was chosen as a sublethal concentration for the induction of premature senescence of hMESCs, whereas apoptosis was tested under higher concentrations of $\mathrm{H}_{2} \mathrm{O}_{2}(900$ and 3,000 $\mu \mathrm{M})$. The cells were washed twice with serum-free medium to remove $\mathrm{H}_{2} \mathrm{O}_{2}$ and then recultured in fresh complete medium for various durations as specified in individual experiments.

2.2. Assessment of Cell Viability. The cell viability after exposure to $\mathrm{H}_{2} \mathrm{O}_{2}$ for $1 \mathrm{~h}$ was evaluated by the enzymatic conversion of MTT (AppliChem, Darmstadt, Germany, number A2231) to formazan in live cells. The culture medium from the cells grown in plates was removed, and 3(4.5-dimethylthiazol-2-yl)-2.5-diphenyltetrazolium bromide
(MTT; 0,715 mg/mL) in serum-containing growth medium was added to each well. In $2 \mathrm{~h}$ the solution was changed to DMSO to solve formazan produced. The plates were shaken for $15 \mathrm{~min}$ at room temperature; thereafter the absorbance was measured at $570 \mathrm{~nm}$ using microplate reader (Fluorofot "Charity," Russia). All points were read as parallels of 8 similar samples. The average absorbance at a given time point was normalized to the start time point.

2.3. Flow Cytometry. Adherent cells were rinsed twice with PBS and harvested by trypsinization. Detached cells were collected with supernatants, pelleted by centrifugation. Detached and adherent cells were finally pooled and resuspended in PBS. One part of each sample was used for propidium iodide (PI) staining to evaluate cell viability and another part for cell cycle phase distribution analysis that was performed as described previously [27]. $50 \mu \mathrm{g} / \mathrm{mL}$ PI was added to each sample just before analysis and mixed gently. Samples were analyzed on a Coulter EPICS XL Flow Cytometer (Backman Coulter, Brea, CA, USA). For cell cycle analysis, each cell sample was suspended in $300 \mu \mathrm{L}$ PBS containing $200 \mu \mathrm{g} / \mathrm{mL}$ of saponin (Fluka, NY, USA), used for cell permeabilization, $250 \mu \mathrm{g} / \mathrm{mL}$ RNase A (Sigma, St. Louis, MO, USA, number R4642), and $50 \mu \mathrm{g} / \mathrm{mL}$ PI, incubated for $30 \mathrm{~min}$ at room temperature and subjected to FACS analysis. At least 10,000 cells were measured per sample. Cell cycle analysis was performed using Win MDI program version 2.8 and ModFit LT software (Verity Software House, Topsham, ME, USA).

2.4. FACS Analysis of Cell Enlargement. The same procedure of sample preparation as described previously was done for light-scattering cytometry. As after $\mathrm{H}_{2} \mathrm{O}_{2}$ treatment live and dead cells were very close to each other on one-parameter histogram, two-parameter histogram was used (FL4LOG versus FSLOG) to discriminate live and dead cells. Analysis of each sample was performed for $100 \mathrm{sec}$ with high sample delivery. Cell size of control and $\mathrm{H}_{2} \mathrm{O}_{2}$-treated cells was measured by means of cytometric light scattering of PIstained cells by using Win MDI program version 2.8.

2.5. SA- $\beta$-Gal Activity. Cells expressing senescent-associated $\beta$-galactosidase were detected with senescence $\beta$-galactosidase staining kit (Cell Signaling Technology, Beverly, MA, USA, number 9860) according to manufacturer's instructions. The kit detects $\beta$-galactosidase activity at $\mathrm{pH} 6$ in cultured cells which is present only in senescent cells and is not found in presenescent, quiescent, or immortal cells. The percent of SA- $\beta$-Gal-positive cells was calculated by counting not less than 500 cells.

2.6. Immunofluorescence Staining. Cells cultured on coverslips were fixed with $\mathrm{PBS} / 4 \%$ formalin for $15 \mathrm{~min}$ and then permeabilized with $0.1 \%$ Triton X-100. After blocking with $1 \%$ bovine serum albumin, they were incubated with a rabbit polyclonal antibody against Ki67 (Abcam, Cambridge, UK, number 15580) $(1: 1000)$ overnight at $4^{\circ} \mathrm{C}$ and then with Alexa Fluor 568 donkey anti-rabbit antibody (Invitrogen, Carlsbad, 
USA, number A10042) (1:500) at room temperature for $1 \mathrm{~h}$ after extensive washing with PBS/0.1\% Tween 20 between each step. The slides were counterstained with $1 \mu \mathrm{g} / \mathrm{mL}$ DAPI (Sigma, St. Louis, MO, USA, number D9564) and mounted using 2\% propyl gallate. A Zeiss Axiovert 200M fluorescence microscope (Carl Zeiss, Germany) equipped with a digital camera DFC 420C (Leica, Germany) utilizing Adobe Photoshop software was used to view and acquire images.

2.7. Apoptosis Detection. Apoptosis detection was performed by Annexin V/PI staining according to standard manufacture protocols (BD Pharmingen). $\mathrm{H}_{2} \mathrm{O}_{2}$-treated and control cells were harvested as described previously. Then cells were washed twice with cold PBS, resuspended in $1 \mathrm{X}$ binding buffer at concentration $10^{6}$ cells $/ \mathrm{mL} .100 \mu \mathrm{L}$ of this suspension was transferred to $5 \mathrm{~mL}$ tube, and $5 \mu \mathrm{L}$ Annexin V/FITC (Annexin V/FITC Apoptosis Detection Kit II, BD Biosciences, San Diego, CA, USA) and $10 \mu \mathrm{L}$ PI were added; suspension was gently mixed and incubated for $15 \mathrm{~min}$ at room temperature in the dark. Just before flow cytometric analysis $400 \mu \mathrm{L}$ of $1 \mathrm{X}$ binding buffer was added to each sample.

2.8. Western Blotting. Total cell lysates were prepared as described previously [27]. Protein content was determined by the method of Bradford. The cell lysates were dissolved in SDS sample buffer and separated on $8 \%$ or $12 \%$ SDS gel. SDSPAGE electrophoresis, transfer to nitrocellulose membrane, and immunoblotting with ECL (Thermo Scientific, USA) detection were performed according to standard manufacturer's protocols (Bio-Rad Laboratories, USA). The following antibodies were used: rabbit monoclonal antibodies against p21 Waf1/Cip1 (12D1, number 2947S) (1:1000) and against glyceraldehyde-3-phosphate dehydrogenase (GAPDH, clone 14C10, number 2118S) (1:1000), as well as horseradish peroxidase-conjugated goat anti-rabbit IG (number 7074S) $(1: 10000)$. All antibodies were purchased from Cell Signaling, USA. Hyperfilm (CEA) was from Amersham (Sweden). Equal protein loading was confirmed by Ponceau S (Sigma, St. Louis, MO, USA, number P7170) staining.

2.9. RT-PCR Assay. To analyze gene expression, total RNA from cells was isolated with RNesy Micro Kit (Qiagen, USA) according to manufacturer's instructions. cDNA synthesis was performed with $1 \mu \mathrm{g}$ of total RNA using RevertAid $\mathrm{H}$ Minus First Strand cDNA Synthesis Kit (Fermentas, Lithuania) according to manufacturer's instructions. Specific genes were amplified by Taq DNA polymerase (Fermentas, Lithuania) with C1000 Touch Thermal Cycler amplifier (BioRad Laboratories, USA). The program was as follows: hot start-denaturation at $93^{\circ} \mathrm{C}$ for $3 \mathrm{~min}$, primer annealing at 51$70^{\circ} \mathrm{C}$ for $2 \mathrm{~min}$, and then elongation at $72^{\circ} \mathrm{C}$ for $1 \mathrm{~min} 30 \mathrm{sec}$; thereafter, 25-27 cycles of denaturation at $93^{\circ} \mathrm{C}$ for $45 \mathrm{sec}$, primer annealing at $51-70^{\circ} \mathrm{C}$ for $1 \mathrm{~min}$, elongation at $72^{\circ} \mathrm{C}$ for $1 \mathrm{~min} 30 \mathrm{sec}$, and then final elongation at $72^{\circ} \mathrm{C}$ for $10 \mathrm{~min}$; primers $p 21^{\text {Waf1/Cip } 1}$, sense $5^{\prime}$ CCA CAT GGT CTT CCT CTG CTG $3^{\prime}$, antisense $5^{\prime}$ GAT GTC CGT CAG AAC CCA
TG $3^{\prime}$, annealing temperature $55^{\circ} \mathrm{C}(316 \mathrm{bp})$; SOD1, sense $5^{\prime}$ GGT CCT CAC TTT AAT CCT CTA T $3^{\prime}$, antisense $5^{\prime}$ CAT CTT TGT CAG CAG TCA CAT T $3^{\prime}$, annealing temperature $62^{\circ} \mathrm{C}$ (96 bp); SOD2, sense $5^{\prime}$ TGA CAA GTT TAA GGA GAA GC $3^{\prime}$, antisense $5^{\prime}$ GAA TAA GGC CTG TTG TTC C $3^{\prime}$, annealing temperature $56^{\circ} \mathrm{C}(148 \mathrm{bp})$; GPX1, sense $5^{\prime}$ CGC CAC CGC GCT TAT GAC CG $3^{\prime}$, antisense $5^{\prime}$ GCA GCA CTG CAA CTG CCA AGC AG $3^{\prime}$, annealing temperature $68^{\circ} \mathrm{C}(238 \mathrm{bp}) ; \beta$-actin gene was used for RNA quantitative control and DNA contamination monitoring: sense primer 5'-GCC GAG CGG GAA ATC GTG CGT-3', antisense $5^{\prime}$-CGG TGG ACG ATG GAG GGG CCG-3', annealing temperature $70^{\circ} \mathrm{C}(507 \mathrm{bp})$. All primers were obtained from SYNTOL (Russia). The electrophoresis of amplified products was performed in $2 \%$ agarose gel with TAE buffer and ethidium bromide. $100 \mathrm{~kb}$ DNA ladder (Fermentas, Lithuania) was used as molecular weight markers. Amplified products were visualized in UV light $(302 \mathrm{~nm})$ with transilluminator and registered with a digital Canon camera.

2.10. Statistics. All data are presented as the mean and standard error of the mean from at least three separate experiments performed. Statistical differences were calculated using the Student's $t$-test and considered significant at ${ }^{*} P<0.05$.

\section{Results and Discussion}

3.1. Cell Viability under Oxidative Stress. $\mathrm{H}_{2} \mathrm{O}_{2}$ treatment of cultured cells is a commonly used model to test oxidative stress susceptibility in different cell types. Accumulating evidence pointed to a high resistance of mesenchymal stem cells to oxidative stress caused by $\mathrm{H}_{2} \mathrm{O}_{2}[28,29]$. On the other hand, it has been recently reported that some types of human mesenchymal stem cells are very sensitive to $\mathrm{H}_{2} \mathrm{O}_{2}$ exposure [9]. Susceptibility of hMESCs to oxidative stress remains unexplored up to date. We earlier reported that hMESCs subjected to prolonged treatment (for $24 \mathrm{~h}$ ) with $\mathrm{H}_{2} \mathrm{O}_{2}$ demonstrated a higher resistance compared with human diploid fibroblasts [30]. In this study, a pulse cell treatment with $\mathrm{H}_{2} \mathrm{O}_{2}$ in varying concentrations from $200 \mu \mathrm{M}$ to $2 \mathrm{mM}$ for $1 \mathrm{~h}$ was applied. Human diploid fibroblasts (HDF) were used as a $\mathrm{H}_{2} \mathrm{O}_{2}$ sensitive cell model to compare effect of $\mathrm{H}_{2} \mathrm{O}_{2}$ cytotoxicity on hMESCs. Firstly, it was necessary to assess hMESCs viability under oxidative stress to examine a sublethal $\mathrm{H}_{2} \mathrm{O}_{2}$ concentration required for further experiments. Previously we have found out that, at a fixed $\mathrm{H}_{2} \mathrm{O}_{2}$ concentration, both cytotoxicity and rate of degradation were dependent on the volume of $\mathrm{H}_{2} \mathrm{O}_{2}$ solution added to the culture medium; therefore the volume used was adjusted proportionally according to the surface area in order to obtain a consistent $\mathrm{H}_{2} \mathrm{O}_{2}$ cytotoxicity. In addition, it was very important to control plating cell density because the $\mathrm{H}_{2} \mathrm{O}_{2}$ effect (at equal volume and concentration) on cells was inversely related to cell density; that is, confluent cell cultures were more resistant to $\mathrm{H}_{2} \mathrm{O}_{2}$ than subconfluent ones. Cell viability was evaluated by MTT assay as a broad indicator of cellular activity that allows estimating a number of viable cells via monitoring mitochondrial dehydrogenase activity. As shown in Figure 1, $\mathrm{H}_{2} \mathrm{O}_{2}$ affected the cell viability of both cell 


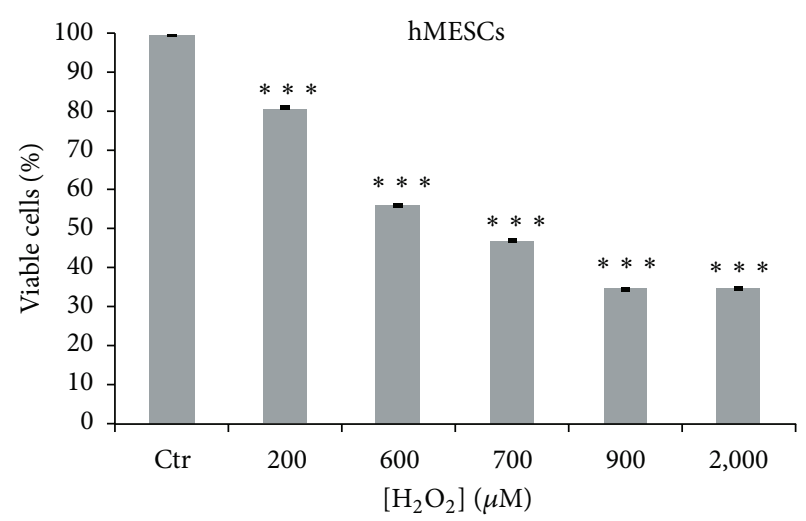

(a)

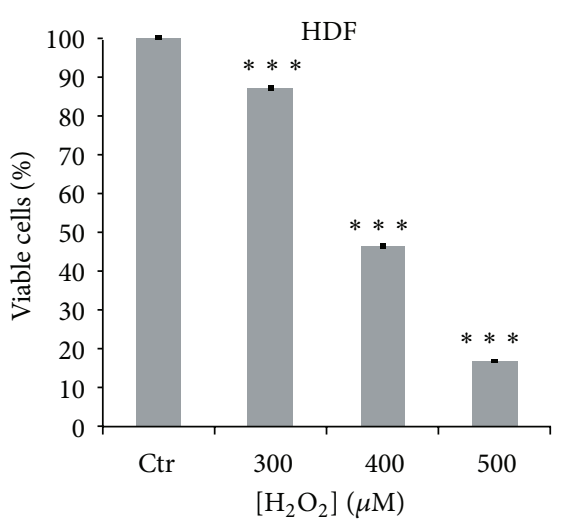

(b)

FIgURE 1: The viability of hMESCs and HDF under oxidative stress. Cells were either treated or not with $\mathrm{H}_{2} \mathrm{O}_{2}$ at indicated concentrations for $1 \mathrm{~h}$. The percentage of viable cells was evaluated in $24 \mathrm{~h}$ after treatment using MTT assay as described in Section 2 . Results are shown as a percent of control. Data represent mean \pm SEM of at least three independent experiments. ${ }^{* * *} P<0.001$ significantly different from the untreated control cells. LD values were 600-700 and 370-400 $\mu \mathrm{M}$ for hMESCs and HDF, respectively. Control (Ctr): untreated cells.

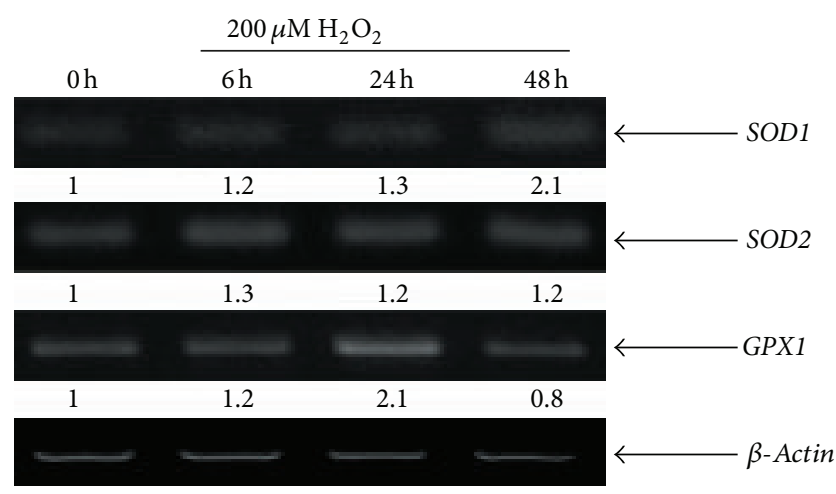

Figure 2: Gene expression of SOD1, SOD2, and GPX1 is enhanced in hMESCs in response to $\mathrm{H}_{2} \mathrm{O}_{2}$ treatment. Exponentially growing cells were treated with the sublethal dose $(200 \mu \mathrm{M})$ of $\mathrm{H}_{2} \mathrm{O}_{2}$ for $1 \mathrm{~h}$ with following $\mathrm{H}_{2} \mathrm{O}_{2}$ replacement and then cultured under normal conditions for the indicated time. Total RNA isolated from hMESCs was amplified with specific primers for referred genes. $\beta$-Actin was used as a loading control.

lines in a dose-dependent manner. $\mathrm{LD}_{50}$ values characterizing cell viability corresponded to $600-700 \mu \mathrm{M}(15-17.5 \mathrm{pmol} / \mathrm{cell})$ for hMESCs and 370-400 $\mu \mathrm{M}$ (3.5-4.0 pmol/cell) for HDF. Thus, hMESCs were found to be very resistant to $\mathrm{H}_{2} \mathrm{O}_{2}$ compared to HDF.

3.2. Expression of Antioxidant Enzymes. To examine whether this high resistance to effect of $\mathrm{H}_{2} \mathrm{O}_{2}$ correlates with the ability of hMESCs to effectively scavenge reactive oxygen species (ROS), expression of the genes coding for enzymes involved in the elimination of ROS such as SOD1, SOD2, and GPX1 was tested. Previously, we have observed a rapid increase of the intracellular ROS levels in hMESCs after exposure to $\mathrm{H}_{2} \mathrm{O}_{2}$ (data not presented). Here, it was shown that, in untreated cells, the basal levels of mRNA expression of all of the antioxidant enzymes were elevated, while after treatment with $200 \mu \mathrm{M} \mathrm{H}_{2} \mathrm{O}_{2}$ an expression level of each enzyme was upregulated to different extent (Figure 2). Consequently, the significant insensitivity to $\mathrm{H}_{2} \mathrm{O}_{2}$ was consistent with the enhanced expression levels of the antioxidant enzymes. These findings are in agreement with previous report demonstrating a high resistance of human bone marrow-derived mesenchymal stem cells to oxidative stress [29]. The conflicting findings demonstrating a particular sensitivity of human umbilical cord blood-derived mesenchymal stem cells to $\mathrm{H}_{2} \mathrm{O}_{2}$ have correlated with the low levels of antioxidant enzyme activity [9].

\subsection{A Sublethal Oxidative Stress Induces a Premature Senes-} cence Phenotype in hMESCs. In hMESCs, phenomenon of $\mathrm{H}_{2} \mathrm{O}_{2}$-induced premature senescence was not so far described. In all experiments, early-passage cells were used to avoid undesirable replicative senescence of cells, because the major features of both replicative and stress-induced senescence are known to be alike $[14,17,18]$. To test whether hMESCs after treatment with a sublethal $\mathrm{H}_{2} \mathrm{O}_{2}$ concentration $(200 \mu \mathrm{M})$ could undergo SIPS, we assessed a variety of senescent-associated biomarkers: change of cell morphology, SA- $\beta$-Gal staining, increasing of cell size, loss of proliferative potential, cell cycle arrest, and p $21^{\text {Waf1/Cip1 }}$ (hereafter p21) status. $\mathrm{H}_{2} \mathrm{O}_{2}$ treatment was found to lead to development of senescent-like morphology: cells become enlarged, flattened, and heterogeneous. It should be noted that, in a part of cell population, we could see such morphological changes within $24 \mathrm{~h}$ after $\mathrm{H}_{2} \mathrm{O}_{2}$ treatment. In addition, senescent cells demonstrated SA- $\beta$-Gal staining which increased gradually, and the most remarkable effect was reached at 7 days after treatment: more 95\% $\mathrm{H}_{2} \mathrm{O}_{2}$-treated cells were SA- $\beta$ Gal positive (Figures 3(a) and 3(b)). Exponentially growing control cells displayed very weak, if any, increase of SA- $\beta-\mathrm{Gal}$ staining. Importantly, a premature senescence phenotype was maintained during the follow-up period of 21 days (data not shown).

The increased heterogeneity of the cellular size of $\mathrm{H}_{2} \mathrm{O}_{2}$ treated hMESCs was further confirmed and quantified by 


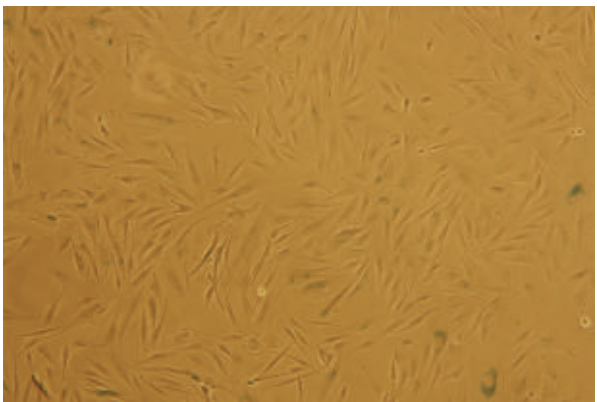

Untreated cells

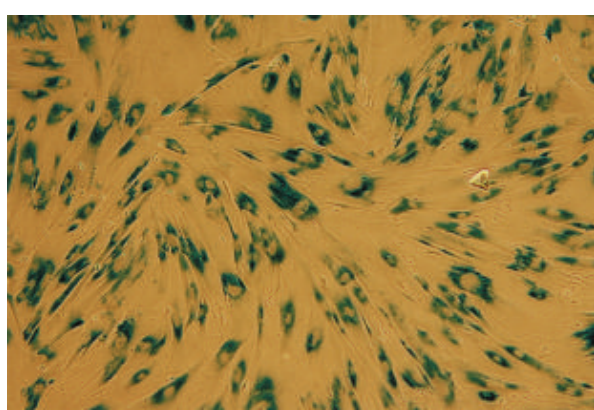

7 days after $\mathrm{H}_{2} \mathrm{O}_{2}$ treatment

(a)

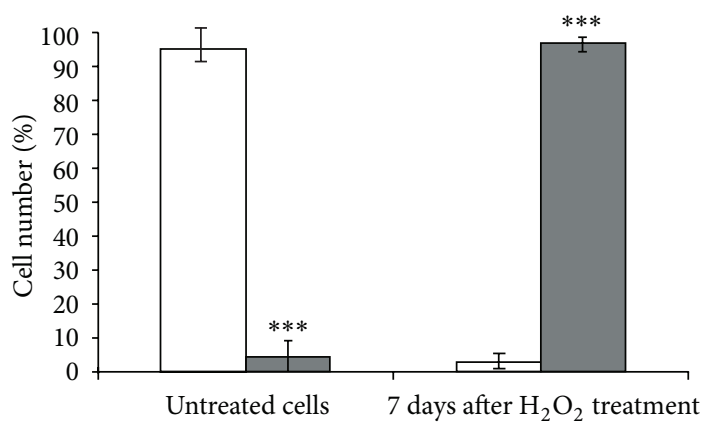

$\square$ SA- $\beta$-Gal negative

$\square$ SA- $\beta$-Gal positive

(b)
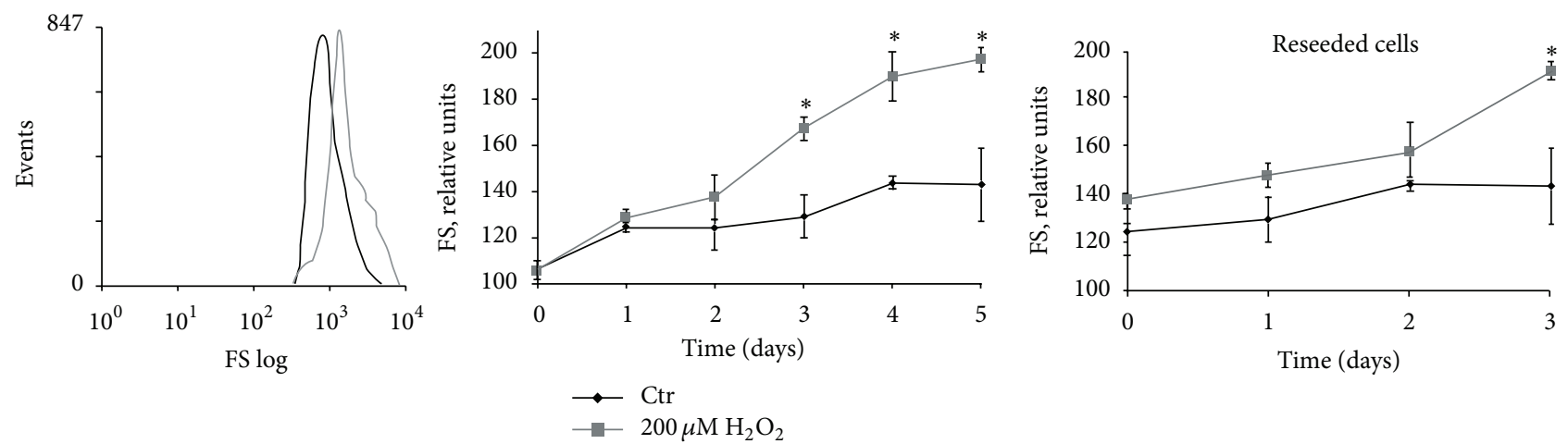

(c)

FIgURE 3: The sublethal dose of $\mathrm{H}_{2} \mathrm{O}_{2}$ induces senescent phenotype in hMESCs. Cells were treated as indicated in the legend of Figure 2. (a) SA- $\beta$-Gal staining. (b) Quantitative assay of SA- $\beta$-Gal-positive cells. (c) $\mathrm{H}_{2} \mathrm{O}_{2}$-induced cell size increase. Typical presentation of forward scatter (FS), reflecting the average cell size (left). Cell size was determined daily: $\mathrm{H}_{2} \mathrm{O}_{2}$-treated cells were either cultured for 5 days under standard conditions (middle) or were reseeded in 2 days and additionally cultivated for 3 days (right). Data were obtained by light-scattering cytometry with using Win MDI program version 2.8. Data represent mean \pm SEM of at least three independent experiments. Significant difference was based on the Student's $t$-test $\left({ }^{*} P<0.05,{ }^{* * *} P<0.001\right)$. Control (Ctr): untreated cells.

light-scattering cytometry of PI-stained cells. As indicated in Figure 3(c), $\mathrm{H}_{2} \mathrm{O}_{2}$ induced a 2-fold increase of cell size after 5 days compared with control, as measured by the shift in the mean value of the forward scatter. The elevated size of treated cells was sustained constant, at least, for 5 days, whereas the size of control cells was almost not changed. To test whether treated hMESCs retain their increased size being reseeded, after $\mathrm{H}_{2} \mathrm{O}_{2}$ treatment cells were cultured for 2 days and then reseeded and additionally cultured under normal cell culture conditions for 3 days. As a result, we observed the similar increase of cell size (1.8-fold) in both reseeded and cultured cells for 5 days without reseeding cells (Figure 3(c)). 


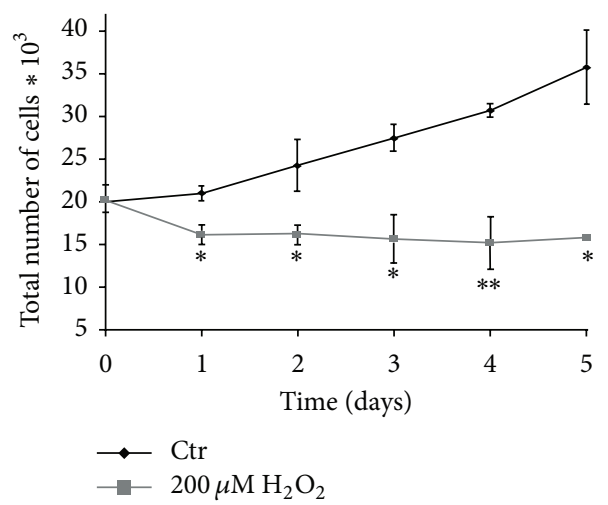

(a)
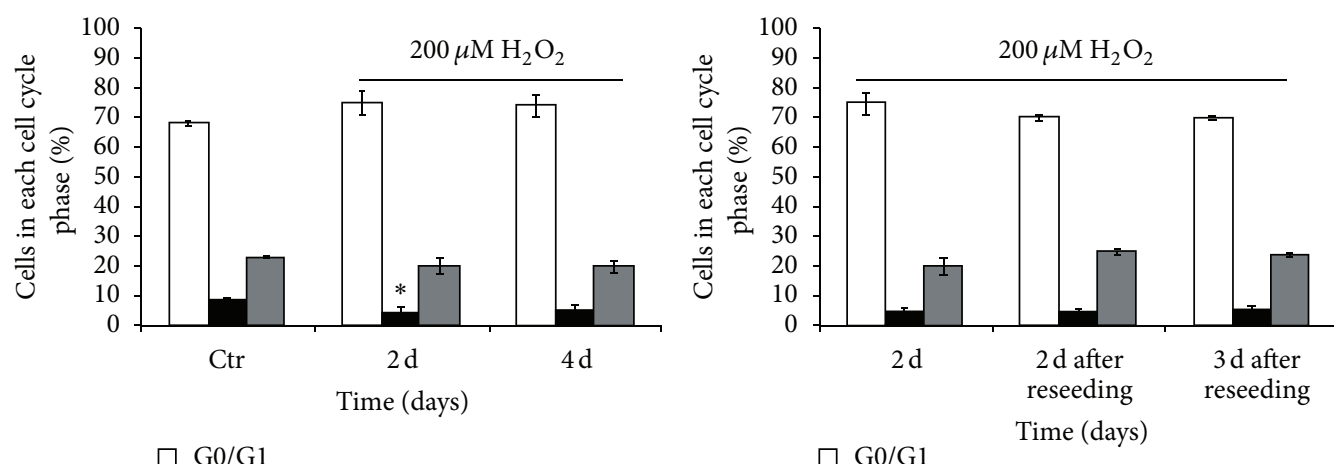

$\square \mathrm{G} 0 / \mathrm{G} 1$

- $\mathrm{S}$

- $\mathrm{S}$

G2/M

$\square \mathrm{G} 2 / \mathrm{M}$

\begin{tabular}{|c|c|c|c|c|c|c|}
\hline $68 \pm 0.79$ & $75 \pm 3.86$ & $74 \pm 3.27$ & G0/G1 & $75 \pm 3.86$ & $70 \pm 0.7$ & $70 \pm 0.36$ \\
\hline $9 \pm 0.56$ & $5 \pm 1.1$ & $6 \pm 1.22$ & S & $5 \pm 1.1$ & $5 \pm 0.75$ & $6 \pm 0.64$ \\
\hline $23 \pm 0.35$ & $20 \pm 2.76$ & $20 \pm 2.05$ & G2/M & $20 \pm 2.76$ & $25 \pm 1.03$ & $24 \pm 0.4$ \\
\hline
\end{tabular}
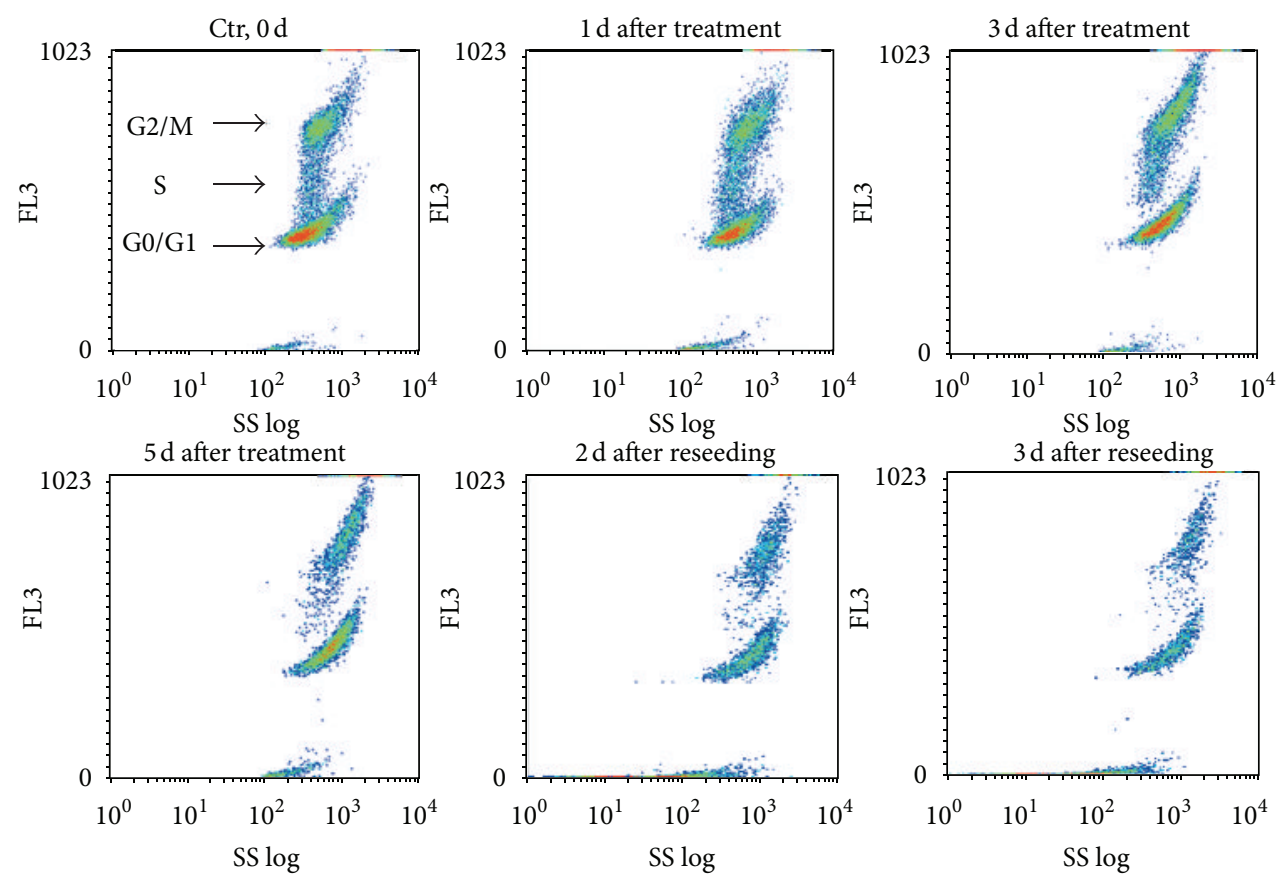

(b)

FIgure 4: Continued. 


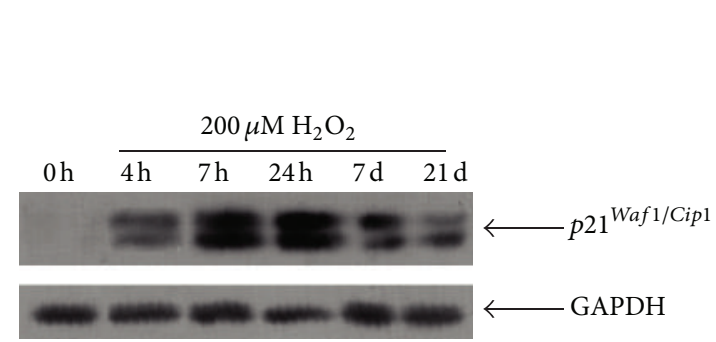

(c)
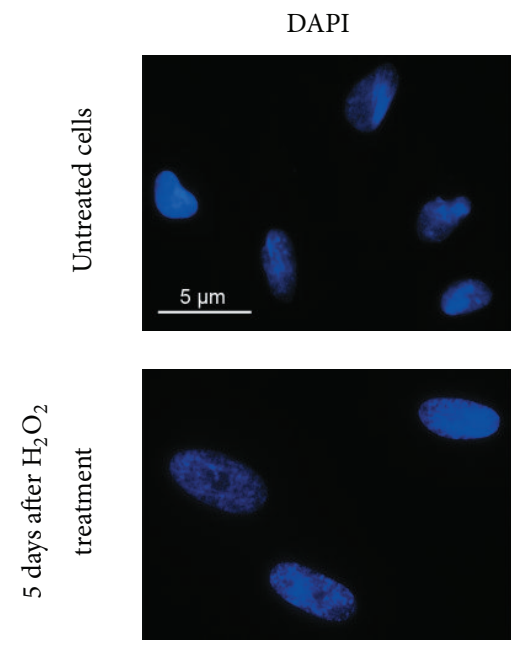
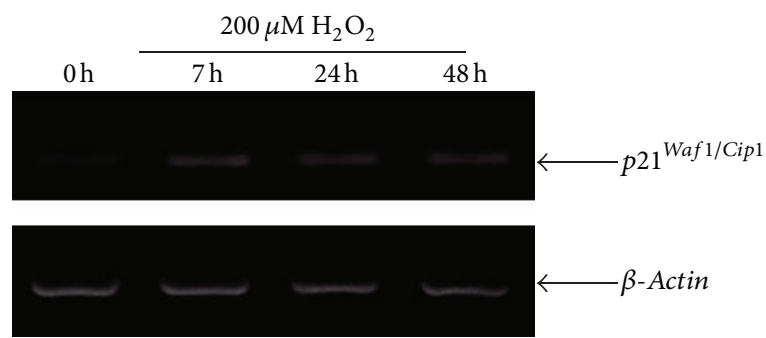

(d)
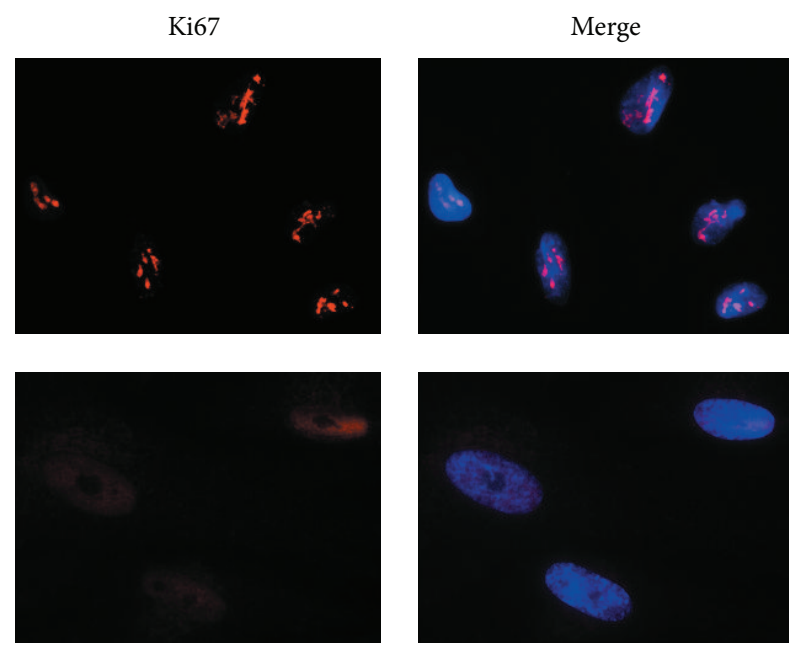

(e)

FIGURE 4: Induction of the premature senescence in hMESCs under oxidative stress leads to the permanent arrest of cell cycle and irreversible loss of proliferative potential. Cell treatment was done as described in Figure 2. (a) Growth curve of both $\mathrm{H}_{2} \mathrm{O}_{2}$-treated and untreated cells. Cell number was determined daily after cell exposure to $\mathrm{H}_{2} \mathrm{O}_{2}$ by FACS analysis $\left(\mathrm{M} \pm \mathrm{SEM}, n=3,{ }^{*} P<0.05\right.$, $\left.{ }^{* *} P<0.01\right)$. (b) $\mathrm{H}_{2} \mathrm{O}_{2}$-treated cells were either cultured for 5 days or were reseeded in 2 days and additionally cultured for 3 days. Flow cytometry analysis of cell cycle phase distribution: the percentage of cells in the G0/G1, S, and G2/M phases (upper panel) ( ${ }^{*} P<0.05$ ); visualization of phase distribution based on light-scattering analysis (lower panel); SS: side scattering, FL3: PI fluorescence. (c) The expression levels of p21 protein. Representative results of the three experiments are shown in the figure. (d) The levels of $p 21$ mRNA expression. GAPDH and $\beta$-actin were used as loading controls. (e) The nuclear localization of Ki67 was tested in control or $\mathrm{H}_{2} \mathrm{O}_{2}$-treated cells by immunofluorescence and DAPI staining. Representative photomicrographs of the staining are shown. Images were taken at magnification 100x. Control (Ctr): untreated cells.

Importantly, cell size increase was accompanied with protein content elevation, suggesting protein synthesis in $\mathrm{H}_{2} \mathrm{O}_{2}$ treated cells. Together, the results obtained demonstrate cellular hypertrophy within hMESCs population in response to $\mathrm{H}_{2} \mathrm{O}_{2}$.

\subsection{The Permanent Cell Cycle Arrest and Loss of the Pro-} liferative Potential in hMESCs Subjected to Sublethal Oxidative Stress. In order to further characterize $\mathrm{H}_{2} \mathrm{O}_{2}$-induced senescent-like state of hMESCs, we analyzed their proliferative potential. Cell number in both untreated and $\mathrm{H}_{2} \mathrm{O}_{2}$ treated cell cultures was counted during 5 days. As seen in Figure 4(a), the pattern of growth curves indicates a significant increase (more than two times in 5 days) in the number of proliferating control cells compared with $\mathrm{H}_{2} \mathrm{O}_{2}$-treated cells. Consequently, $200 \mu \mathrm{M} \mathrm{H} \mathrm{H}_{2} \mathrm{O}_{2}$ caused a permanent growth arrest, that is, a permanent loss of the proliferative potential. Additionally, a proliferative status of cells was examined by staining with antibodies against proliferation marker Ki67. As seen in Figure 4(e), in 5 days after $\mathrm{H}_{2} \mathrm{O}_{2}$ treatment, there were no Ki67-positive cells in the cell culture, while the proliferating control cells had a pronounced staining. As viability of hMESCs in response to $200 \mu \mathrm{M} \mathrm{H}_{2} \mathrm{O}_{2}$ did not decrease appreciably (Figure 1), we suggested that $\mathrm{H}_{2} \mathrm{O}_{2}$-induced growth inhibition of hMESCs could be associated with rather the cell cycle arrest than promotion of cell death.

The analysis of the cell cycle phase distribution in hMESCs showed that a pulse $\mathrm{H}_{2} \mathrm{O}_{2}$ treatment led to the arrest in all of the cycle phases (Figure 4(b), upper panel). Treated cells demonstrated the prolonged arrest, at least, for 5 days. The phase distribution of treated cells in each time point tested was characterized with a minor accumulation of cells in G0/G1 phase compared with control cells. The distribution analysis with using light scattering confirmed these findings (Figure 4(b), lower panel). To test whether arrested cells could recover their proliferative potentials, in 2 days after treatment cells were reseeded and cultivated for 3 more days. As expected, reseeded cells also displayed the cell cycle arrest. Moreover, cell cycle phase distributions of both reseeded 


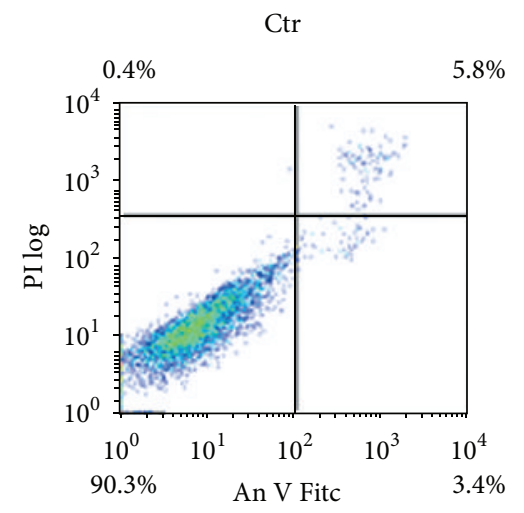

Control

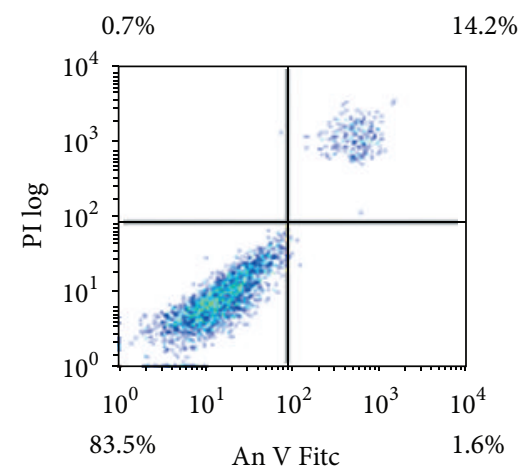

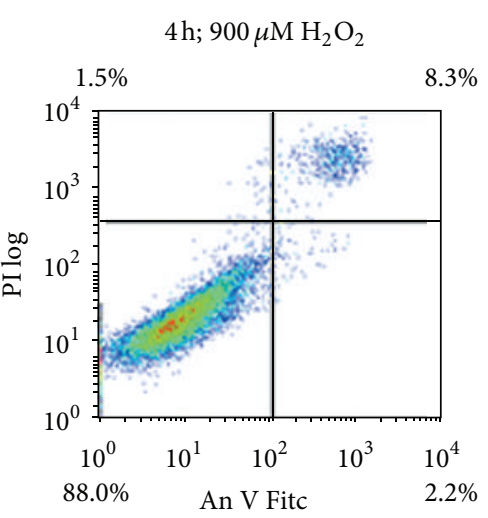

$24 \mathrm{~h} ; 3,000 \mu \mathrm{M} \mathrm{H}_{2} \mathrm{O}_{2}$

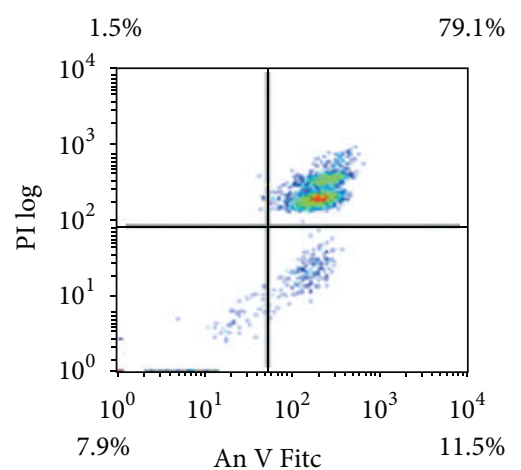

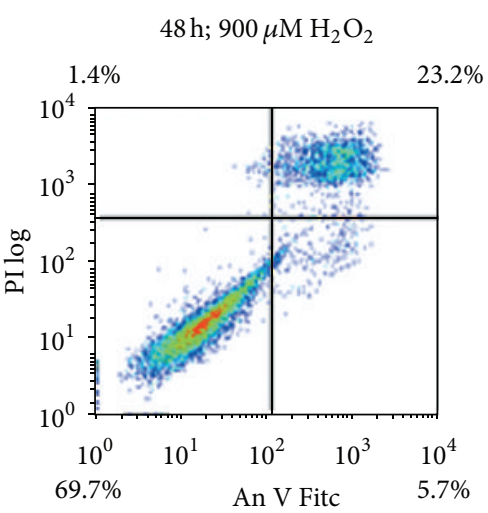

$48 \mathrm{~h} ; 3,000 \mu \mathrm{M} \mathrm{H}_{2} \mathrm{O}_{2}$

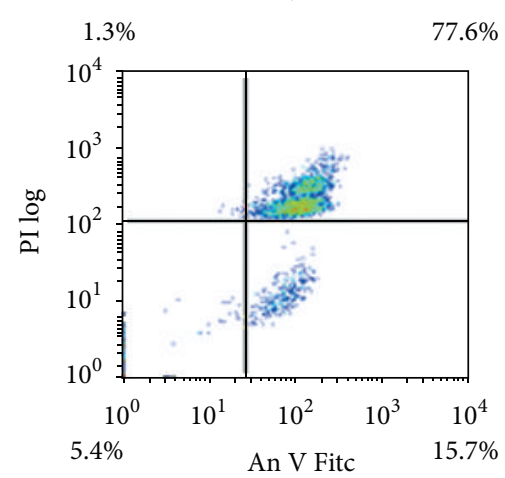

FIGURE 5: Dot plots of FITC-annexin V/PI flow cytometry. hMESCs were subjected to $900 \mu \mathrm{M}$ or 3,000 $\mu \mathrm{M} \mathrm{H}_{2} \mathrm{O}_{2}$ for $1 \mathrm{~h}$ with following $\mathrm{H}_{2} \mathrm{O}_{2}$ replacement and cell cultivation under normal conditions. Apoptosis was detected at indicated time points. Control (Ctr): untreated cells.

and taken-before-reseeding cells were identical (Figure 4(b)). Consequently, the senescent cells were not able to resume proliferation even after being reseeded, indicating the irreversible growth arrest. These observations were confirmed by proliferation assay (Figure 4(a)), which demonstrated that $\mathrm{H}_{2} \mathrm{O}_{2}$-treated cells were not able to proliferate normally for 5 days. Overall, these results suggest that cellular senescence in hMESCs was induced through growth arrest by $\mathrm{H}_{2} \mathrm{O}_{2}$.

\subsection{A Permanent Loss of the Proliferative Potential in hMESCs} Is Accompanied with Elevated Levels of p21. In human mesenchymal stem cells, cyclin-dependent kinase inhibitor p21 was recently shown to be upregulated during $\mathrm{H}_{2} \mathrm{O}_{2}$-induced premature senescence $[7,8]$. Increased levels of p21 may mediate the initiation of $\mathrm{H}_{2} \mathrm{O}_{2}$-induced cell cycle arrest by inhibiting various cyclin-dependent kinases that contribute cell cycle phase progression $[14,16]$. To find out whether p21 could be involved in the regulation of $\mathrm{H}_{2} \mathrm{O}_{2}$-induced senescence of hMESCs, protein and mRNA expression levels of p21 were determined. $200 \mu \mathrm{M} \mathrm{H}_{2} \mathrm{O}_{2}$ promoted a significant elevation in protein (Figure 4(c)) and mRNA (Figure 4(d)) expression of $\mathrm{p} 21$ in $7 \mathrm{~h}$ after treatment. An inducible expression of p21 was upregulated during 1-2 days with a following decline to insignificant, but not control, levels and was accompanied with the cell cycle arrest at the same time (Figure 4(b)). Importantly, the arrested cells thereafter could acquire a senescent morphology (Figure 3(a)) but could not resume proliferation (Figure 4(a)). We assume that the elevated p21 expression is essential to drive $\mathrm{H}_{2} \mathrm{O}_{2}$ induced premature senescence in hMESCs. In support of our findings, it has been reported that, in bone marrow-derived mesenchymal stem cells exposed to sublethal doses of $\mathrm{H}_{2} \mathrm{O}_{2}$, a rapid decrease of proliferation rate was detected within 3 days and correlated with G1 phase arrest of the cell cycle when p21 was accumulated at the same time [8].

In summary, our findings strongly indicate that hMESCs under a sublethal oxidative stress are able to undergo premature senescence.

3.6. Effect of High $\mathrm{H}_{2} \mathrm{O}_{2}$ Doses on hMESCs. $\mathrm{H}_{2} \mathrm{O}_{2}$ is well documented to cause apoptosis by a dose-dependent manner in various cell types. According to our data, at $200 \mu \mathrm{M} \mathrm{H}_{2} \mathrm{O}_{2}$, no apoptosis was detected in the cell population up to day 21; therefore we tested here whether $\mathrm{H}_{2} \mathrm{O}_{2}$ at a high concentration causes apoptosis in hMESCs. In order to detect apoptosis, annexin V/PI staining was performed. As presented in Figure 5, upper panel, $900 \mu \mathrm{M} \mathrm{H}_{2} \mathrm{O}_{2}$ reduced the number of viable cells from $90.3 \%$ to $69.7 \%$ in $48 \mathrm{~h}$ after treatment by increasing the number of AnV/PI+ cells. Remarkably, no significant changes in the number of early apoptotic cells $(\mathrm{AnV}+)$ compared with control were observed for $48 \mathrm{~h}$. By contrast, $\mathrm{H}_{2} \mathrm{O}_{2}$ at higher concentration $(3,000 \mu \mathrm{M})$ caused apoptosis with no evidence of necrosis in a similar pattern but with much stronger effect (Figure 5, lower panel). Thus, the apoptotic levels in $\mathrm{H}_{2} \mathrm{O}_{2}$-treated hMESCs were regulated by a dose-dependent manner. According to our 


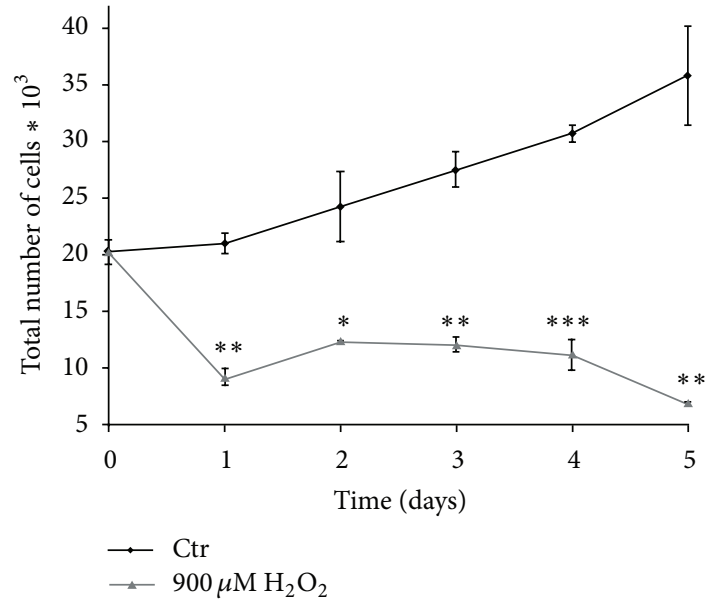

(a)

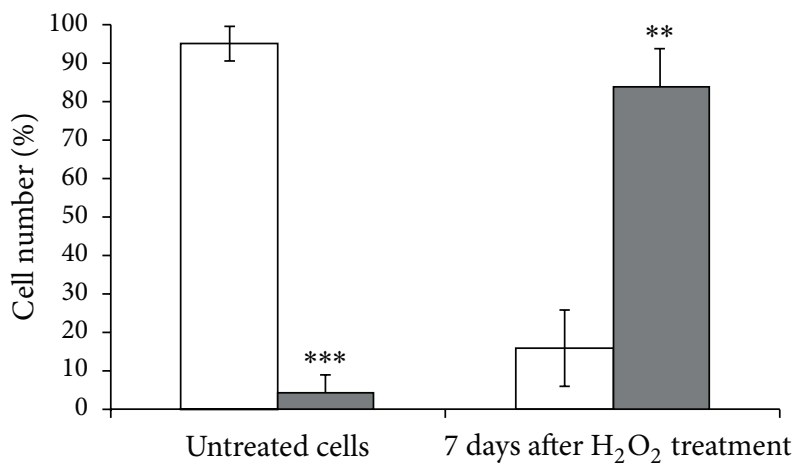

$\square$ SA- $\beta$-Gal negative

$\square$ SA- $\beta$-Gal positive

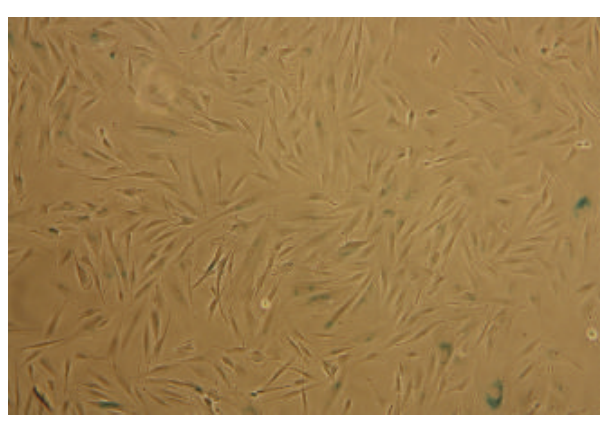

Untreated cells

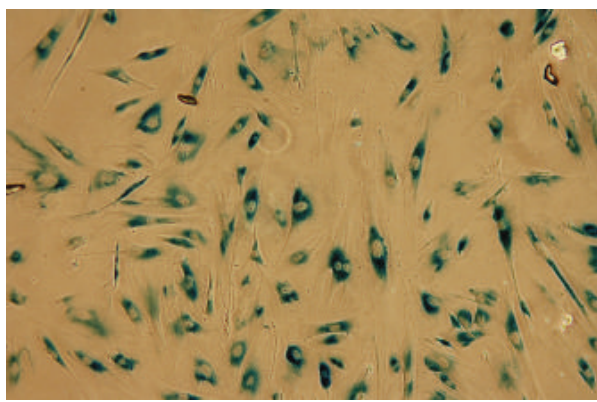

7 days after $\mathrm{H}_{2} \mathrm{O}_{2}$ treatment

(b)

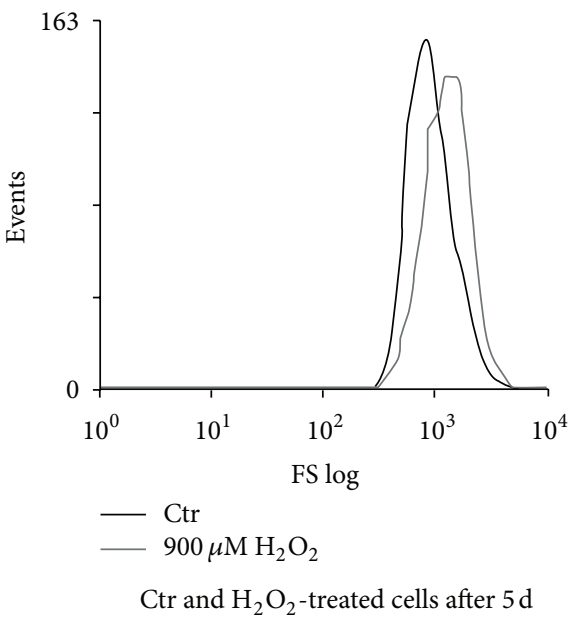

(d)

FIGURE 6: The senescent phenotype in hMESCs treated with $900 \mu \mathrm{M} \mathrm{H}_{2} \mathrm{O}_{2}$. (a) $\mathrm{H}_{2} \mathrm{O}_{2}$-induced inhibition of cell proliferation ( \pm SEM, $n=3$ ). (b) SA- $\beta$-Gal staining. (c) Quantitative assay of SA- $\beta$-Gal-positive cells. (d) Cell hypertrophy detected by light-scattering cytometry. Significant difference was based on the Student's $t$-test $\left({ }^{*} P<0.05,{ }^{* *} P<0.01\right.$, and $\left.{ }^{* * *} P<0.001\right)$. Control (Ctr): untreated cells.

preliminary results, apoptosis was mediated by both caspase8 and activated caspase-3; however, the exact mechanism of $\mathrm{H}_{2} \mathrm{O}_{2}$-induced apoptosis in hMESCs remains to be further elucidated.

Interestingly, $900 \mu \mathrm{M} \mathrm{H} \mathrm{H}_{2} \mathrm{O}_{2}$ triggered not only delayed apoptosis but also led to the emergence of enlarged and flattened cells in the same cell cultures. Cell changes in the presence of both $200 \mu \mathrm{M}$ and $900 \mu \mathrm{M} \mathrm{H} \mathrm{H}_{2} \mathrm{O}_{2}$ were similar in appearance. These observations prompted us to test if cell hypertrophy could be connected with premature senescence. As shown in Figure 6, $900 \mu \mathrm{M} \mathrm{H}_{2} \mathrm{O}_{2}$ actually promoted the senescent morphology and SA- $\beta-\mathrm{Gal}$ staining, permanent growth arrest, and approximately 2fold increase of cell size, pointing to premature senescence of the main part of cell population. Notably, the major senescence features induced by both $200 \mu \mathrm{M}$ and $900 \mu \mathrm{M}$ $\mathrm{H}_{2} \mathrm{O}_{2}$ were found to be alike. Together, these findings demonstrate that hMESCs exhibit high apoptosis resistance compared with human mesenchymal stem cells derived from both umbilical cord blood [9] and bone marrow [7], in which $\mathrm{H}_{2} \mathrm{O}_{2}$ above $200 \mu \mathrm{M}$ triggered apoptosis, whereas $100-$ $150 \mu \mathrm{M} \mathrm{H}_{2} \mathrm{O}_{2}$ induced senescence. Moreover, after exposure 
to sublethal doses of $\mathrm{H}_{2} \mathrm{O}_{2}$, senescent hMESCs acquired the increased stability in culture and displayed enhanced resistance to $\mathrm{H}_{2} \mathrm{O}_{2}$-induced apoptosis (data not shown). Many cell types acquire resistance to some apoptotic signals when they become senescent. So, senescent human fibroblasts resist apoptosis induced by oxidative stress or growth factor deprivation but do not resist Fas-mediated apoptosis [31, 32]. Resistance to apoptosis might in part explain the enhanced stability of senescent cells in culture. The mechanisms by which senescent cells resist apoptosis are poorly investigated. The senescence and apoptosis regulatory systems are supposed to communicate probably through their common regulator, p53 tumor suppressor protein [33].

In this study, we have provided the reliable evidence for our hypothesis that hMESCs are able to undergo the premature senescence in response to oxidative stress induced by $\mathrm{H}_{2} \mathrm{O}_{2}$ in a wide range of concentrations from 200 to $900 \mu \mathrm{M}$. According to data obtained, entering senescence was accompanied with a rapid initiation of the cellular events, such as the changes of cell phenotype, the increase of SOD1, SOD2, and GPX1 expression, and upregulation of p21 without increase over time, leading to the irreversible cell cycle arrest and loss of proliferative potential. Since 2009, when phenomenon of stress-induced premature senescence in human mesenchymal stem cells was described for the first time, there were only a few publications concerning the oxidative stress-induced premature senescence of human mesenchymal cells derived from bone marrow $[7,8]$ and umbilical cord blood [9]. Even though both stem cell lines under sublethal stress respond with senescence, the major features of this process, in particular, dynamics of p21 accumulation and decline of cell proliferation rate, were extremely different, depending on the cell context. The precise molecular mechanism required to regulate the oxidative stressinduced premature senescence of human mesenchymal stem cells is far from understanding. Senescence program seems to develop in mesenchymal stem cells as a result of DNA damage response, leading to functional activation of either the $\mathrm{p} 53 / \mathrm{p} 21$ or the p16INK4a (p16)/retinoblastoma protein $(\mathrm{pRb})$ pathway, both of which can establish and maintain the growth arrest that is typical of senescence $[23,24]$. The cyclin-dependent kinase inhibitors p16 and p21 may maintain $\mathrm{pRb}$ in active hypophosphorylated state [34, 35]. In turn, $\mathrm{pRb}$ halts cell proliferation by suppressing the activity of transcription factor E2F that regulates cell cycle progression. Our preliminary data, indicating a time- and dose-dependent formation of foci that contain phosphorylated histone H2AX $(\gamma \mathrm{H} 2 \mathrm{AX})$, activation of both ATM and $\mathrm{p} 53$, and upregulation of p21 expression, suggest that in hMESCs subjected to sublethal doses of $\mathrm{H}_{2} \mathrm{O}_{2}$ the senescence process may be controlled by the p53 pathway. In parallel, by monitoring the kinetics of $\mathrm{p} 38$ mitogen-activated protein kinase (MAPK) activation in $\mathrm{H}_{2} \mathrm{O}_{2}$-induced senescence of hMESCs, we have revealed a rapid and continued phosphorylation of p38 MAPK, indicating its possible role in the regulation of the premature senescence [36]. On the other hand, pRb was reported to induce growth arrest as a downstream molecule of p38 MAPK [37]. Taking into consideration these results, we cannot exclude the possibility that $\mathrm{p} 16 / \mathrm{pRb}$ signaling cascade is also implicated in hMESCs senescence promotion.

Understanding the mechanisms of senescence process will be of great importance in developing applications of hMESCs in regenerative medicine to provide new strategies in autologous transplant and bioengineering. Primarily, hMESCs may be applied for cell therapy of infertility associated with decidualization insufficiency. Decidualization of endometrium is known to be an essential process for embryo implantation, placenta forming, and maintenance of pregnancy [38]. A noninvasive and easily available source for isolation of hMESCs, high proliferation activity during longterm cultivation, genetic stability, lack of tumorigenicity [39], and low immunogenicity make hMESCs a promising source of stem cells for clinical applications, including reproduction technology.

In summary, we have displayed for the first time that hMESCs in oxidative stress conditions undergo a premature senescence. Data obtained broaden a conception of mesenchymal stem cell senescence under oxidative stress. Taken together, the findings presented here and the data published allow us to assume that induction of premature senescence might be a common physiological response to sublethal oxidative stress in human mesenchymal stem cells of any origin.

\section{Abbreviations}

hMESCs: Human endometrium-derived mesenchymal stem cells

HDF: Human diploid fibroblasts

SIPS: $\quad$ Stress-induced premature senescence

$\mathrm{H}_{2} \mathrm{O}_{2}$ : Hydrogen peroxide

FACS: $\quad$ Flow-activated cell sorting

SA- $\beta$-Gal: Senescence-associated $\beta$-galactosidase

SOD1: $\quad$ Cytosolic superoxide dismutase

SOD2: Mitochondrial superoxide dismutase

GPX1: Glutathione peroxidase.

\section{Acknowledgments}

The authors thank Alekseenko L. L. (Institute of Cytology) for help with RT-PCR. This research was supported by Grants of MCB RAS and from the Russian Foundation for Basic Research (RFBR) (11-04-01581-a).

\section{References}

[1] W. R. Otto and N. A. Wright, "Mesenchymal stem cells: from experiment to clinic," Fibrogenesis and Tissue Repair, vol. 4, no. 1, article 20, 2011.

[2] M. F. Pittenger, A. M. Mackay, S. C. Beck et al., "Multilineage potential of adult human mesenchymal stem cells," Science, vol. 284, pp. 143-144, 1999.

[3] C. Toma, M. F. Pittenger, K. S. Cahill, B. J. Byrne, and P. D. Kessler, "Human mesenchymal stem cells differentiate to a cardiomyocyte phenotype in the adult murine heart," Circulation, vol. 105, no. 1, pp. 93-98, 2002.

[4] M. K. Majumdar, M. A. Thiede, J. D. Mosca, M. Moorman, and S. L. Gerson, "Phenotypic and functional comparison of 
cultures of marrow-derived mesenchymal stem cells (MSCs) and stromal cells," Journal of Cellular Physiology, vol. 176, pp. 57-66, 1998.

[5] N. E. Sharpless and R. A. DePinho, "How stem cells age and why this makes us grow old," Nature Reviews Molecular Cell Biology, vol. 8, no. 9, pp. 703-713, 2007.

[6] J. Campisi, S.-H. Kim, C.-S. Lim, and M. Rubio, "Cellular senescence, cancer and aging: the telomere connection," Experimental Gerontology, vol. 36, no. 10, pp. 1619-1637, 2001.

[7] A. Brandl, M. Meyer, V. Bechmann, M. Nerlich, and P. Angele, "Oxidative stress induces senescence in human mesenchymal stem cells," Experimental Cell Research, vol. 317, no. 11, pp. 15411547, 2011.

[8] J.-S. Kim, E.-J. Kim, H.-J. Kim, J.-Y. Yang, G.-S. Hwang, and C.-W. Kim, "Proteomic and metabolomic analysis of $\mathrm{H}_{2} \mathrm{O}_{2}$ induced premature senescent human mesenchymal stem cells," Experimental Gerontology, vol. 46, no. 6, pp. 500-510, 2011.

[9] E. Ko, K. Y. Lee, and D. S. Hwang, "Human umbilical cord blood-derived mesenchymal stem cells undergo cellular senescence in response to oxidative stress," Stem Cells and Development, vol. 21, pp. 1877-1886, 2012.

[10] D. Wang and D.-J. Jang, "Protein kinase CK2 regulates cytoskeletal reorganization during ionizing radiation-induced senescence of human mesenchymal stem cells," Cancer Research, vol. 69, no. 20, pp. 8200-8207, 2009.

[11] Á. M. Prendergast, S. Cruet-Hennequart, G. Shaw, F. P. Barry, and M. P. Carty, "Activation of DNA damage response pathways in human mesenchymal stem cells exposed to cisplatin or $\gamma$ irradiation," Cell Cycle, vol. 10, no. 21, pp. 3768-3777, 2011.

[12] J. Cmielova, R. Havelek, T. Soukup et al., "Gamma radiation induces senescence in human adult mesenchymal stem cells from bone marrow and periodontal ligaments," International Journal of Radiation Biology, vol. 88, no. 5, pp. 393-404, 2012.

[13] E. E. Medrano, S. Im, F. Yang, and Z. A. Abdel-Malek, "Ultraviolet $B$ light induces $G_{1}$ arrest in human melanocytes by prolonged inhibition of retinoblastoma protein phosphorylation associated with long- term expression of the p21( $\left.{ }^{W a f-1 / S D I-1 / C i p-1}\right)$ protein," Cancer Research, vol. 55, no. 18, pp. 4047-4052, 1995.

[14] O. Toussaint, E. E. Medrano, and T. Von Zglinicki, "Cellular and molecular mechanisms of stress-induced premature senescence (SIPS) of human diploid fibroblasts and melanocytes," Experimental Gerontology, vol. 35, no. 8, pp. 927-945, 2000.

[15] C.-W. Oh, E. A. Bump, J.-S. Kim, D. Janigro, and M. R. Mayberg, "Induction of a senescence-like phenotype in bovine aortic endothelial cells by ionizing radiation," Radiation Research, vol. 156, no. 3, pp. 232-240, 2001.

[16] Q. M. Chen, J. C. Bartholomew, J. Campisi, M. Acosta, J. D. Reagan, and B. N. Ames, "Molecular analysis of $\mathrm{H}_{2} \mathrm{O}_{2}$-induced senescent-like growth arrest in normal human fibroblasts: p53 and $\mathrm{Rb}$ control $\mathrm{G}_{1}$ arrest but not cell replication," The Biochemical Journal, vol. 332, pp. 43-50, 1998.

[17] P. Dumont, M. Burton, Q. M. Chen et al., "Induction of replicative senescence biomarkers by sublethal oxidative stresses in normal human fibroblast," Free Radical Biology and Medicine, vol. 28, no. 3, pp. 361-373, 2000.

[18] C. Frippiat, Q. M. Chen, S. Zdanov, J.-P. Magalhaes, J. Remacle, and $\mathrm{O}$. Toussaint, "Subcytotoxic $\mathrm{H}_{2} \mathrm{O}_{2}$ stress triggers a release of transforming growth factor- $\beta 1$, which induces biomarkers of cellular senescence of human diploid fibroblasts," Journal of Biological Chemistry, vol. 276, no. 4, pp. 2531-2537, 2001.

[19] J. Duan, J. Duan, Z. Zhang, and T. Tong, "Irreversible cellular senescence induced by prolonged exposure to $\mathrm{H}_{2} \mathrm{O}_{2}$ involves DNA-damage-and-repair genes and telomere shortening," International Journal of Biochemistry and Cell Biology, vol. 37, no. 7, pp. 1407-1420, 2005.

[20] V. V. Ogryzko, T. H. Hirai, V. R. Russanova, D. A. Barbie, and B. H. Howard, "Human fibroblast commitment to a senescencelike state in response to histone deacetylase inhibitors is cell cycle dependent," Molecular and Cellular Biology, vol. 16, no. 9, pp. 5210-5218, 1996.

[21] V. S. Romanov, M. V. Abramova, S. B. Svetlikova et al., "p21Waf1 is required for cellular senescence but not for cell cycle arrest induced by the HDAC inhibitor sodium butyrate," Cell Cycle, vol. 9, no. 19, pp. 3945-3955, 2010.

[22] M. V. Blagosklonny, "Cell cycle arrest is not yet senescence, which is not just cell cycle arrest: terminology for TOR-driven aging," Aging, vol. 4, pp. 159-165, 2012.

[23] J. Campisi and F. D’Adda Di Fagagna, "Cellular senescence: when bad things happen to good cells," Nature Reviews Molecular Cell Biology, vol. 8, no. 9, pp. 729-740, 2007.

[24] F. Rodier and J. Campisi, "Four faces of cellular senescence," Journal of Cell Biology, vol. 192, no. 4, pp. 547-556, 2011.

[25] S. Momtaz and M. Abdollahi, "A comprehensive review of biochemical and molecular evidences from animal and human studies on the role of oxidative stress in aging: an epiphenomenon or the cause," Asian Journal of Animal and Veterinary Advances, vol. 7, no. 1, pp. 1-19, 2012.

[26] V. I. Zemel'ko, T. M. Grinchuk, A. P. Domnina et al., "Multipotent mesenchymal stem cells of desquamated endometrium: isolation, characterization and use as feeder layer for maintenance of human embryonic stem cell lines," Tsitologiia, vol. 53, no. 12, pp. 919-929, 2011.

[27] E. B. Burova, I. S. Smirnova, I. V. Gonchar, A. N. Shatrova, and N. N. Nikolsky, "Inhibition of the EGF receptor and ERK1/2 signaling pathways rescues the human epidermoid carcinoma A431 cells from IFN $\gamma$-induced apoptosis," Cell Cycle, vol. 10, no. 13, pp. 2197-2205, 2011.

[28] M.-F. Chen, C.-T. Lin, W.-C. Chen et al., "The sensitivity of human mesenchymal stem cells to ionizing radiation," International Journal of Radiation Oncology Biology Physics, vol. 66, no. 1, pp. 244-253, 2006.

[29] A. Valle-Prieto and P. A. Conget, "Human mesenchymal stem cells efficiently manage oxidative stress," Stem Cells and Development, vol. 19, no. 12, pp. 1885-1893, 2010.

[30] E. B. Burova, O. G. Lublinskaya, A. N. Shatrova, A. V. Borodkina, and N. N. Nikolsky, "Comparison of human endometrial stem cells and fibroblasts resistance to oxidative stress," Tsitologiia, vol. 54, pp. 478-483, 2012.

[31] Q. M. Chen, J. Liu, and J. B. Merrett, "Apoptosis or senescencelike growth arrest: influence of cell-cycle position, p53, p21 and bax in $\mathrm{H}_{2} \mathrm{O}_{2}$ response of normal human fibroblasts," The Biochemical Journal, vol. 347, no. 2, pp. 543-551, 2000.

[32] C. G. Tepper, M. F. Seldin, and M. Mudryj, "Fas-mediated apoptosis of proliferating, transiently growth-arrested, and senescent normal human fibroblasts," Experimental Cell Research, vol. 260, no. 1, pp. 9-19, 2000.

[33] A. Seluanov, V. Gorbunova, A. Falcovitz et al., "Change of the death pathway in senescent human fibroblasts in response to DNA damage is caused by an inability to stabilize p53," Molecular and Cellular Biology, vol. 21, no. 5, pp. 1552-1564, 2001.

[34] G. H. Stein, L. F. Drullinger, A. Soulard, and V. Dulić, "Differential roles for cyclin-dependent kinase inhibitors p21 and p16 
in the mechanisms of senescence and differentiation in human fibroblasts," Molecular and Cellular Biology, vol. 19, no. 3, pp. 2109-2117, 1999.

[35] J. J. L. Jacobs and T. De Lange, "Significant role for p16INK4a in p53-independent telomere-directed senescence," Current Biology, vol. 14, no. 24, pp. 2302-2308, 2004.

[36] J. Maruyama, I. Naguro, K. Takeda, and H. Ichijo, "Stressactivated MAP kinase cascades in cellular senescence," Current Medicinal Chemistry, vol. 16, no. 10, pp. 1229-1235, 2009.

[37] H. Iwasa, J. Han, and F. Ishikawa, "Mitogen-activated protein kinase p38 defines the common senescence-signalling pathway," Genes to Cells, vol. 8, no. 2, pp. 131-144, 2003.

[38] J. J. Kim, H. S. Taylor, Z. Lu et al., "Altered expression of HOXA10 in endometriosis: potential role in decidualization," Molecular Human Reproduction, vol. 13, no. 5, pp. 323-332, 2007.

[39] A. P. Domnina, I. I. Fridlyanskaya, V. I. Zemelko et al., "Mesenchymal stem cells from human endometrium do not undergo spontaneous transformation during long-term cultivation," Cell and Tissue Biology, vol. 7, pp. 221-226, 2013. 


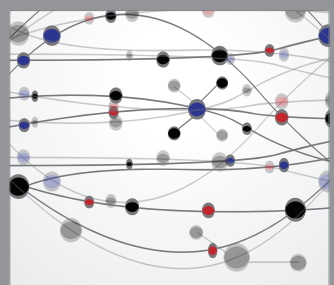

The Scientific World Journal
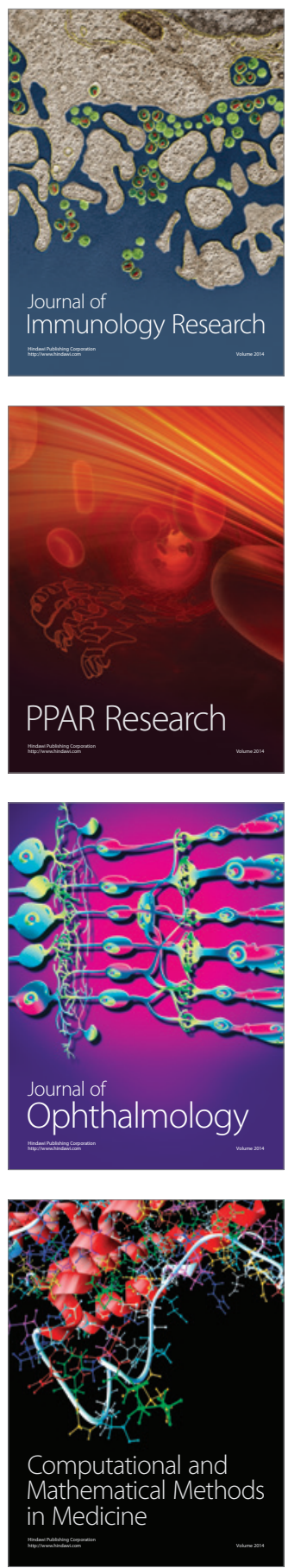

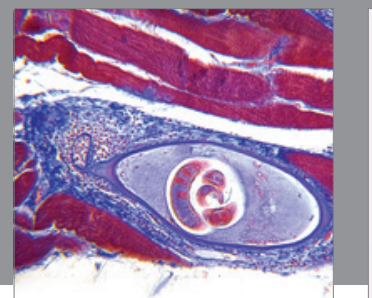

Gastroenterology

Research and Practice
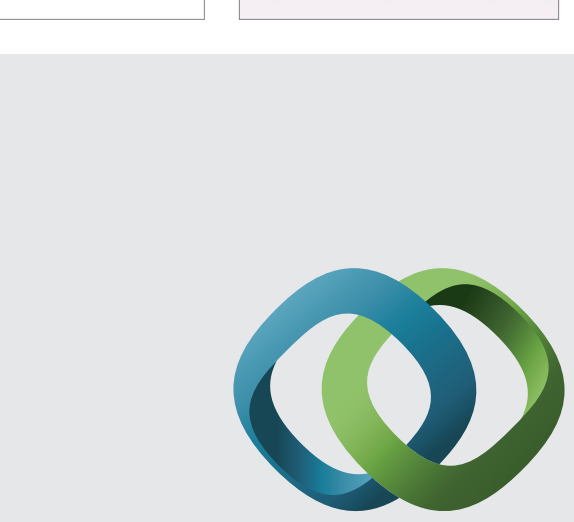

\section{Hindawi}

Submit your manuscripts at

http://www.hindawi.com
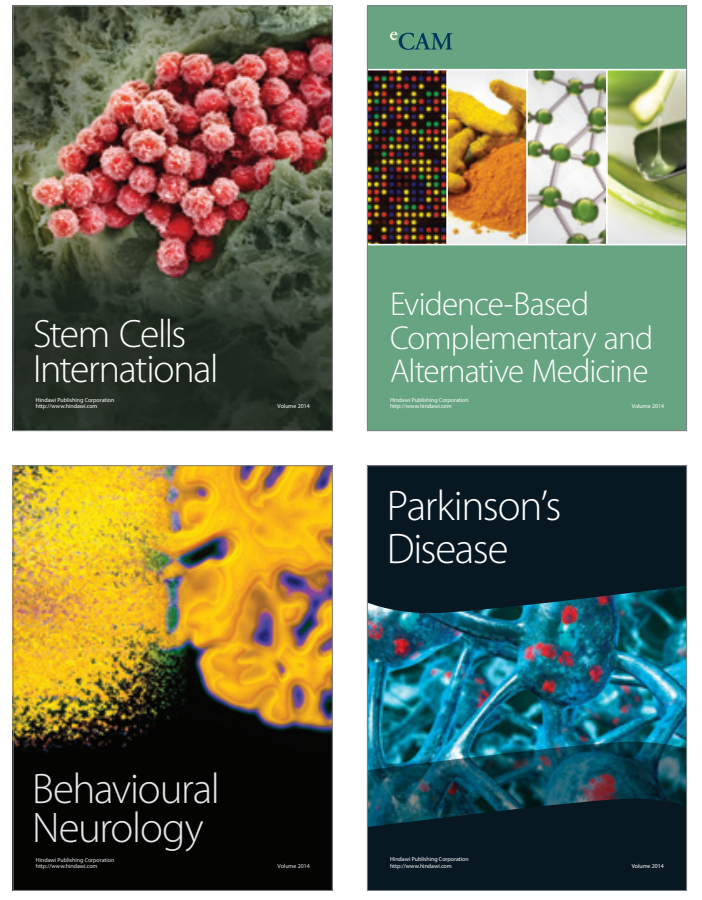
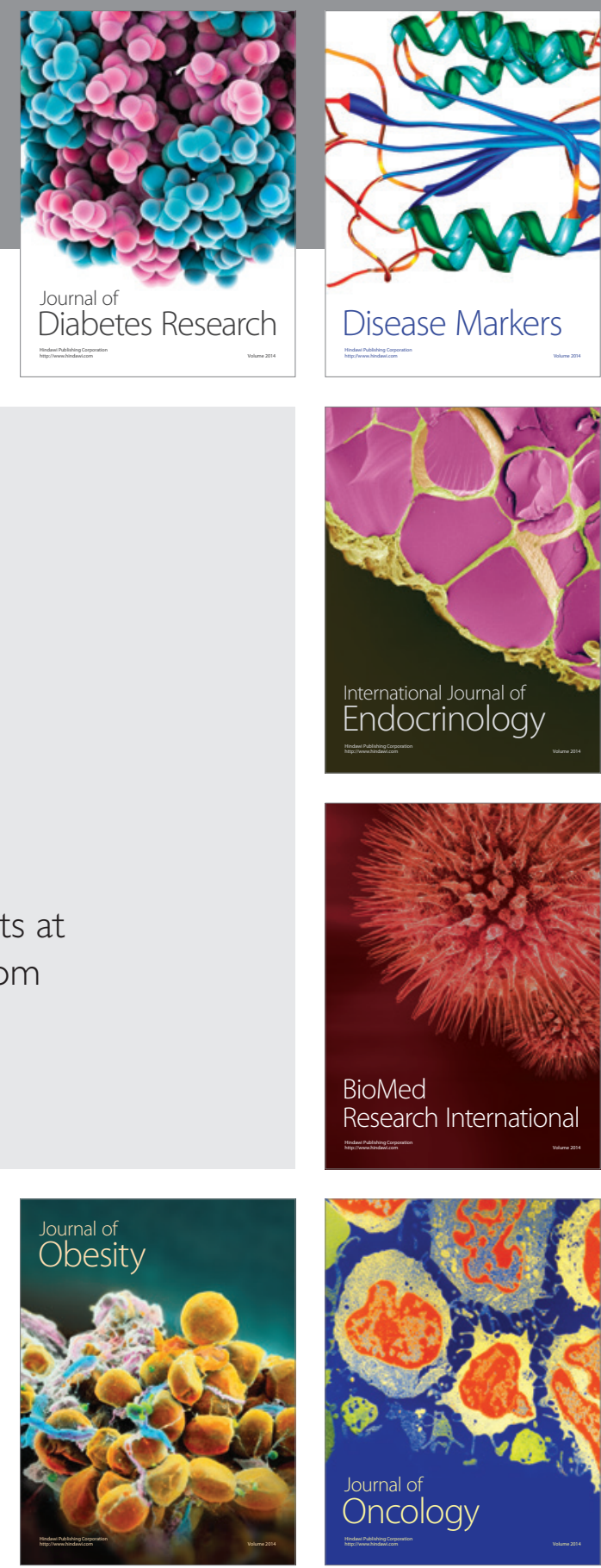

Disease Markers
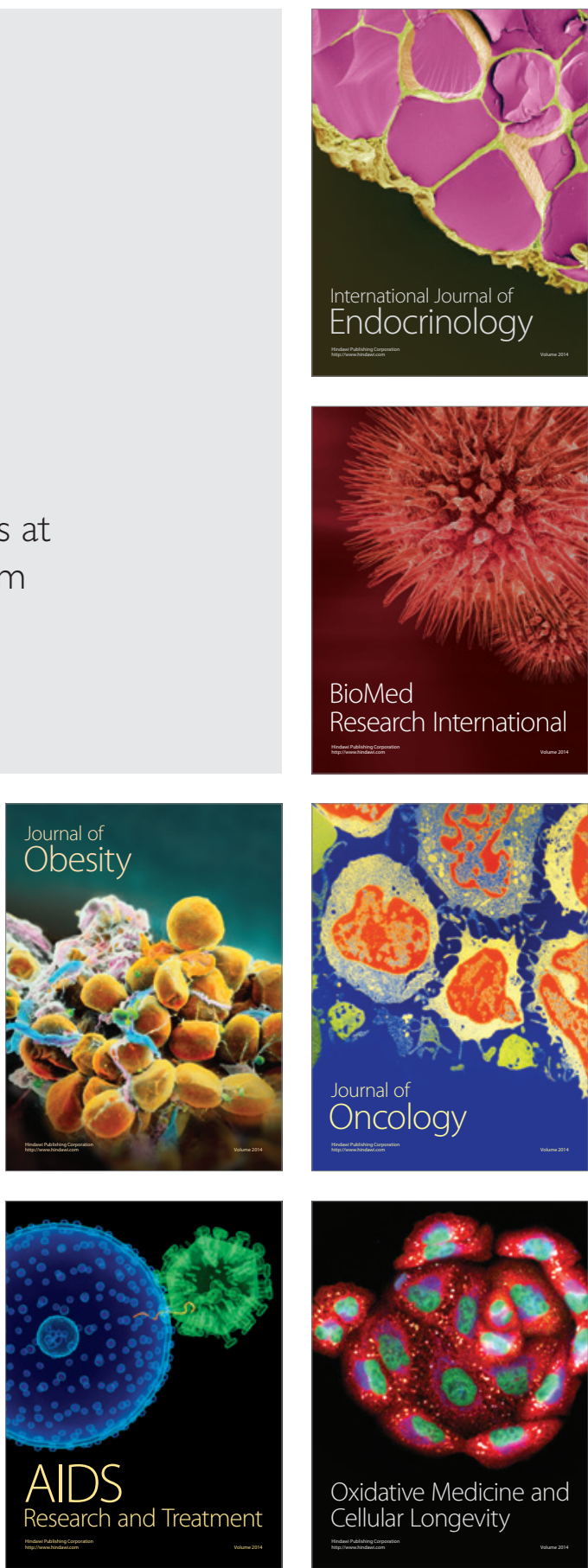